\title{
A LÍNGUA REFÚGIO
}

\author{
THE REFUGE LANGUAGE
}

LA LENGUA REFUGIO

Alexei Conte Indursky*

\section{RESUMO}

Este artigo propóe-se pensar a especificidade da clínica com refugiados com base no uso da língua de acolhimento por parte do analisando e seus destinos na transferência. Mais especificamente, visa-se a pensar como o encontro com língua do analista, pelo enlace transferencial, pode engajar o sujeito em um movimento de ida e vinda entre sua língua de origem e a de acolhimento, que promova a desintoxicação dos conteúdos traumáticos operada pela sua transcrição em outra espacialidade psíquica; hipótese clínica que nomeia este artigo. Para tanto, propõe-se a revisão teórica do termo "tradução" na bibliografia psicanalítica, notadamente a partir da obra inédita no Brasil de Janine Altounian, atentando ao "papel tradutor" que a transferência opera ante episódios traumáticos não metabolizados pelo psiquismo. A seguir, uma vinheta clínica é utilizada para ilustrar os debates teóricos suscitados.

Palavras-chave: Refúgio. Língua. Transferência. Tradução. Trauma.

\begin{abstract}
This paper aims to think about the specificity of a clinic with refugees based on the use of the host language from the patient and the destinations in the transference. More specifically, it's argued how the encounter with the language of the analyst, through the transferential bond, can engage one in a movement of coming and going between its original language and the host's, that promotes the detoxification of the traumatic contents operated by its transcription in another psychic spatiality; clinical hypothesis that names this paper. Therefore, the theoretical revision of the term "translation" in the psychoanalytical bibliography is proposed, notably from the unpublished work in Brazil by Janine Altounian, paying attention to the "translating role" that the transference operates on traumatic episodes not metabolized by the psyche. A clinical vignette is then used to illustrate the theoretical discussions.
\end{abstract}

Keywords: Refuge. Language. Transference. Translation. Trauma.

\footnotetext{
Texto recebido em 13 de maio de 2017 e aprovado para publicação em 26 de feverreiro de 2018.

*Doutor e mestre em Psicanálise e Psicopatologia pela Universidade Sorbonne Paris 7, Denis-Diderot. E-mail: alexei.indursky@ gmail.com. Endereço: Rua Felipe de Oliveira, 734, casa 02 - Petrópolis, Porto Alegre-RS, Brasil. CEP: 90630-000.
} 


\section{RESUMEN}

Este artículo se propone pensar la especificidad de la clínica con refugiados a partir de la utilización de la lengua del país huésped por el analizando y sus destinos en la transferencia. Más específicamente, el objetivo es pensar cómo el encuentro con la lengua del analista, a través del enlace transferencial, puede comprometer el sujeto en un movimiento de ida y vuelta entre su lengua de origen y la de acogida que promueva la desintoxicación de los contenidos traumáticos operada por su transcripción en otra espacialidad psíquica; hipótesis clínica que nombra a este artículo. Para ello, se propone una revisión teórica del término 'traducción' en la literatura psicoanalítica, notablemente a partir de la obra inédita en Brasil de Janine Altounian, teniendo en cuenta el "rol traductor" que la transferencia opera frente a episodios traumáticos no metabolizados por el psiquismo. A continuación, se usa una viñeta clínica para ilustrar los debates teóricos planteados.

Palabras clave: Refugio. Lengua. Transferencia. Traducción. Trauma.

\section{INTRODUÇÃO}

P ensar a clínica do exílio implica levar em conta a especificidade, para além do deslocamento geográfico, de tudo o que divide, separa e liga o sujeito com o Outro e que, em determinado momento de sua travessia, retorna como traço, letra ou resto não metabolizado da ruptura que o engendra. Afastado de suas ancoragens narcísicas e de sua constelação simbólica estruturante, o refugiado tem de defrontar-se com diversos desafios, sendo a diferença de culturas e línguas um dos principais. Ante situações de desamparo extremo, os significantes que apresentam o sujeito para si são "desenvelopados" de sua estrutura linguística, despertando elementos pré-linguísticos (sons, afetos, gestos) que invadem o psiquismo do sujeito em exílio.

Devido à importância dessa ruptura, a clínica do exílio tem como um de seus traços prevalentes a resistência no engajamento de pacientes em tratamentos de longo prazo. A bibliografia aponta dificuldades relacionadas à diferença cultural entre analista e analisando como fator preponderante (Nathan, 1984; Tourn, 2003; Pestre, 2010), bem como diagnósticos precipitados de psicose ainda oriundos da psiquiatria colonialista (Moro, \& Lachal, 2012). Poucos autores dedicaram, no entanto, um estudo detalhado sobre o enlace transferencial advindo de situações da clínica intercultural e suas condições de possibilidade. Neste artigo, ${ }^{1}$ interessa-me pensar como o uso da língua do país de acolhimento

\footnotetext{
${ }^{1}$ Este artigo apresenta resultados finais inéditos da pesquisa de doutoramento em Psicanálise e Psicopatologia realizada na Universidade Sorbonne Paris 7, sob o título de De l'exil à l'asile. Cliniques avec des refugies au carrefour entre le psychique e le politique.
} 
por parte do refugiado, investida pela transferência ao longo do processo analítico, pode se constituir em um refúgio psíquico ao sujeito, a fim de testemunhar os episódios traumáticos a si mesmo.

Certamente, o vasto terreno relativo à aprendizagem de uma nova língua é um parâmetro pertinente para pensar o processo de elaboração dos episódios de violência vivenciados durante o exílio e na integração em uma nova cultura. No entanto não almejo aqui essa dimensão da aculturação; dessa seara de pesquisa me interessa especificamente a escolha, inconsciente ou não, de certos refugiados de se exilarem na língua do país de acolhimento. Isto é, pensar como o encontro com uma nova língua engaja o sujeito em um movimento de ida e vinda entre sua língua de origem e a de acolhimento que permite não somente uma circulação entre as tópicas psíquicas, mas abre a possibilidade de uma espécie de desintoxicação dos conteúdos traumáticos operada pela sua transcrição em outra espacialidade psíquica.

\section{LÍNGUA E EXÍLIO}

Quando perguntada por Gunter Gaüs por que permanecera fiel à língua alemã apesar da eclosão do nazismo, Hannah Arendt respondeu com ar descontraído: "O que fazer se finalmente não foi a língua alemã que ficou louca?", acrescentando logo após, "nada pode substituir a língua materna" (Arendt, 2021). Passadas algumas décadas, essa resposta curiosa, por assim dizer, encontrou no pensamento de Derrida uma inquietude com relação à forma quase ingênua de colocar tal questão. $O$ filósofo franco-argelino pergunta se Arendt não vislumbrava a possibilidade de a loucura habitar a língua. Ou ainda, indaga-se Derrida (2001), talvez a pensadora alemã tente semear a dúvida lá onde ela gostaria de ter uma certeza, justamente nesse abrigo de hospitalidade inefável que é a língua materna.

Não é por acaso que dois pensadores que se viram obrigados a buscar refúgio se questionem sobre a questão da língua: esta se encontra no coração da experiência do exílio. Pode-se dizer que não se compreende um sem o outro. $\mathrm{O}$ exílio da língua e o exílio na língua encontram-se intimamente ligados, de forma que, para que alguém fale ao outro, é preciso exilar-se, reconhecer uma separação inaugural entre si e o outro. Esse exílio ontológico marca o sujeito do desejo, acusando o recalcamento originário que, no entanto, nunca poderá ser nomeado como tal. Ao falar, o sujeito está implicado em uma espécie de atualização constante entre o hiato da língua que ele fala e da língua materna pela qual é falado. Esse hiato é o lugar do ato criativo, mas também da vergonha; a hontologie que Lacan (1992) alcunha para trazer à tona a vergonha que tal 
separação ontológica suscita. Posição dupla que engaja o sujeito com sua voz, seu corpo, sua intimidade no apelo de ser compreendido pelo outro, ou seja, de receber um suporte para seu desejo e que, todavia, remete-o a possibilidade inerente do engano, do ato falho, da incompreensão.

Nesse sentido, não raro, a experiência de falar uma língua estrangeira é vivenciada com sofrimento por muitos refugiados, visto que expóe esse exílio da língua; o sujeito, que já se encontra investido na posição de estrangeiro, é compelido a falar a língua do Outro, a fim de ter sua fala e verdade reconhecida, reatualizando assim uma posição infantil de dependência ante o outro detentor do código da linguagem. Cientes desses impasses produzidos pela diferença cultural, o dispositivo clínico criado para acolher e atender refugiados reassentados pelo ACNUR no Brasil opta, sempre que possível, por empregar a língua do refugiado, como gesto de hospitalidade a facilitar o engajamento desses sujeitos na proposta de falarem sobre seus percursos de vida. No entanto, ao longo dessa experiência, notou-se a insistência de certos sujeitos em realizar uma mudança de língua e traduzir certos sentimentos, afetos e imagens que não pareciam ser pronunciáveis em sua língua de origem, ou ainda, que careciam de outra espacialidade psíquica para serem significados. Gesto de exílio na língua do outro que se anunciava, precisamente por sua insistência, como prenhe de sentidos possíveis em suas travessias clínicas.

Interrogamo-nos sobre a emergência desses afetos, sentimentos que retornam ao sujeito em exílio. A desestabilização do universo sensorial fortemente ligado ao comércio do sujeito com seu ambiente sociocultural faz emergir, mediante o trabalho da negatividade da pulsão, significantes pré-linguísticos que retornam ao sujeito e passam a ser investidos pelo psiquismo, seja como furos de significação, seja como significantes enigmáticos a respeito de sua travessia, sua origem, sua verdade. Nesse momento, a despeito da assertiva de Arendt, a língua materna pode, sim, ser habitada pela loucura da incompreensão, da insuficiência da palavra, da ambivalência de sentimentos de rejeição e atração originários do funcionamento do psiquismo e anteriores à emergência da língua. Trata-se de um sofrimento que ainda não pode ser colocado em palavras e passa investir o corpo como último refúgio de descarga pulsional (Indursky, \& Conte, 2015).

Interessa-me pensar como a língua, precisamente por sua capacidade de se deslocar com o sujeito (a despeito da terra de origem e dos objetos perdidos que lá permanecem), pode realizar uma ação continente de reenlaçar tais elementos pré-linguísticos a significantes que permitam atualizar e apresentar o sofrimento experimentado ao sujeito. Desta feita, levantamos a hipótese que muitas vezes o sofrimento experimentado pelo sujeito em sua terra de origem não pode ser expresso na mesma língua em que foi vivido, como se esta permanecesse 
contaminada pelos restos não metabolizados dos episódios de violência e do exílio. Seguindo essa hipótese, a tradução de certos episódios e afecções em outra língua sugere um recurso de refúgio na língua importante para tematizá-los e simbolizá-los.

\section{TRADUÇÃO DO TRAUMA OU TRANSFERÊNCIA TRADUTORA?}

Se, de fato, pode-se sustentar que a escolha de refugiar-se na língua do país de acolhimento supõe uma inscrição simbólica de conteúdos ainda não representados, tal hipótese não deixa de suscitar questôes pertinentes ao uso plural do conceito de "tradução" na teoria psicanalítica. A questão que subjaz aqui é cernir conceitualmente qual operação está implicada nesse movimento que alcunhamos de refúgio na língua. Para abordar essa problemática, realizaremos uma breve discussão focada na obra de Altounian (2005) sobre heranças traumáticas e tradução.

Em $O$ intraduzivel, a autora trilha o percurso que ela própria viveu ao traduzir um velho manuscrito deixado pelo pai que, para sua grande surpresa, versava sobre sua travessia no exílio, ao escapar do genocídio armênio perpetrado pelo Império Turco. Para tanto, a via principal utilizada pela autora é o ato de tradução, cuja aproximação se dá por uma dupla via: como herdeira de um sobrevivente e como tradutora da obra de Freud. De um lado, o intraduzível (pelo qual ela afirma ser habitada) que lhe foi transmitido por seu pai através da impossibilidade de "compartilhar ternamente" as histórias do genocídio armênio. $O$ intraduzível, sobre o qual se apoia seu trabalho de "tradução de restos", proviria das marcas de uma grande dor enquistada entre as gerações e do não reconhecimento sociopolítico do primeiro genocídio do século XX. Esse duplo desmentido teria instaurado uma interdição de habitar a língua armênia, tornando a autora estrangeira à sua própria herança, cuja tradução seria a via principal pela qual ela pode operar um vai e vem entre estes dois registros, histórico e genealógico. A transitividade da língua funcionando como um móbile entre as tópicas e as gerações implicaria, segundo a autora, uma transição ou uma "transnacionalização" do trauma, espécie de passarela intersubjetiva e intrapsíquica a desintoxicar os registros da psyché.

Por outro lado, como tradutora da obra freudiana ao francês, ela alega apreender a incongruência ou não correspondência entre dois sistemas de pensamentos. Seu exercício de tradução permitir-lhe-ia tematizar melhor esse ponto cego entre as línguas e heranças: 
Assim, traduzir uma ausência de língua em uma língua que faz advir a língua ausente à fala, trazer à escritura um passado traumático infantil ou transgeracional que até então não dispunha de palavras, constituem uma operação não sem relação com a tradução de uma língua à outra: em cada uma das duas posturas, o tradutor é o único a conhecer a não coincidência de valências, seja entre dois sistemas de pensamento, seja entre um pensamento sobrevivente à morte psíquica de uma parte de si e a outra que resta incólume a esta fragmentação (Altounian, 2007, p. 173, tradução nossa).

Essa tomada de posição da autora coloca uma questão crucial no seio da noção de "tradução" em psicanálise. Podemos dizer que a operação de tradução realizada entre dois sistemas de língua é a mesma que entre uma parte psíquica fragmentada de si e sua parte incólume? Com efeito, ao longo de sua obra, essa operação "não sem relação com a tradução" acaba se assimilando ao ato de tradução propriamente dito. Dessa feita, sustento a necessidade de se pensar o que está em jogo em tal operação, quando o analisando transita de uma língua à outra.

Efetivamente, o modelo do aparelho psíquico esboçado por Freud $(1895 / 1990)^{2}$ no Projeto sugere um funcionamento tradutivo do aparelho psíquico. O psiquismo trataria de traduzir quantuns de intensidade física em traços mnésicos psíquicos através de transcrições consecutivas, partindo tanto de uma via progrediente (da percepção ao inconsciente) quanto de uma via regrediente (do inconsciente à extremidade motora ou consciência). A passagem de um registro a outro pressupõe sempre uma nova transcrição, cujo código é sempre heterogêneo àquele que o precedeu. No entanto, adverte Freud nessa passagem, há sempre um resto, fueros, que resiste à tradução simbólica, o que causaria esse código em permanente transformação; aquilo que resiste à tradução retorna à consciência/percepção ora como representação de coisa, ora como significante enigmático. Segundo Laplanche (1992), um dos psicanalistas que mais exploraram a metáfora tradutiva, é do "recusamento" (Versangung) da tradução entre as tópicas que emerge o recalque como solução à liquidação de energia psíquica. Ou seja, aquilo que não foi traduzido pelo psiquismo é recalcado para ser ressignificado a posteriori.

Uma corrente psicanalítica francesa, amparando-se e expandindo as hipóteses de Laplanche, sustenta que a tradução desses significantes de demarcação enigmáticos em significantes linguísticos, graças à fala, é a função fundamental da psicanálise. Anzieu (1996), seguindo as explorações de Laplanche, defende que seria precisamente nesse processo de envelopamento dos significantes que a ruptura experimentada pelo sujeito em exílio tocaria. Janine Altounian parece situar-se como herdeira dessa corrente de pensamento quando propóe que, em

\footnotetext{
${ }^{2}$ A primeira data indica o ano de publicação da obra, e a segunda, a edição consultada pelo autor, a qual somente será pontuada na primeira citação da obra no texto. Nas seguintes, será registrada apenas a data de publicação original.
} 
sua travessia de elaboração, "o exilado deve traduzir os traços destes primeiros referentes existenciais nos que deverão doravante servir de enquadre às novas modalidades de investimentos de objeto" (Altounian, 2007, p. 179).

Para tanto, ela se apoia no célebre texto de Sigmund Freud (1914/2010), Recordar, repetir e elaborar, chamando a atenção para a advertência de Freud sobre a resistência em casos nos quais "o analisando não recorda absolutamente o que foi esquecido e reprimido, mas sim o atua" (Freud, 1914, p. 112). A autora insiste que a própria transferência está permeada na obra de Freud por esse papel tradutor "de domar a compulsão de repetição do paciente e transformála num motivo para a recordação" (Freud, 1914, p. 113). Com efeito, sabemos que o papel primeiro da transferência não se limita a uma regressão temporal, mas implica a transitividade das tópicas psíquicas. Assim, quando da abertura dessa arena de embates, a língua, através da fala analítica, passa a ser investida como um móbile entre as tópicas, passando por uma espécie de desagregação ou disjunção dos efeitos metafóricos e metonímicos da linguagem. Daí o efeito secundário da transferência de decomposição da língua em elementos prélinguísticos, presentes nas bordas entre o real e o simbólico. Se a compulsão à repetição seria esse mecanismo de defesa que realiza uma espécie de "tradução em ato" dos significantes impedidos de passar ao pré-consciente, a autora insiste que tal modelo teria sido concebido sob a perspectiva de uma clínica das neuroses. Como pensar uma perlaboração dos episódios ante a ausência da ação do recalque ou em casos de transgeracionalidade do trauma? Para tanto, ela avança a hipótese do ato de tradução como suplência simbólica ao recalque, propondo uma tríplice ação tradutora: inumar os restos não recalcados, inscrevêlos e confiar a um terceiro os restos da catástrofe.

Mais recentemente, Nassikas (2011), ao responder à obra de Altounian, sustenta que o "envelopamento dos restos" pela ação continente dos signos linguísticos, ainda que possa realizar uma suplência simbólica ao inumar e historicizar os episódios traumáticos, não consiste em uma tradução do trauma. O que está em jogo, segundo o autor, é menos a simbolização de um signo linguístico estrangeiro do que o transporte de elementos pré-linguísticos realizado pela ação da transferência; ponderação com a qual estou de acordo.

Transpondo tais consideraçôes ao contexto de uma clínica do exílio, minha preocupação aqui é pensar o trabalho incontornável suscitado pelo enlace transferencial, quando um paciente escolhe, de forma consciente ou não, trocar a língua falada na sessão. Assim, interessa-me compreender a maneira pela qual são investidos, na arena da transferência, esses elementos pré-linguísticos sem figurabilidade psíquica pelo processo secundário, como restos perceptivos (à imagem do trabalho do sonho), ou ainda, conteúdos não metabolizados que, ao 
serem endereçados durante o processo analítico, acabam sendo traduzidos para a língua do anfitrião. Proponho pensar essa hipótese com base em uma vinheta clínica.

\section{CASO VICENTE ${ }^{3}$}

Vicente é um jovem colombiano, vindo ao Brasil por meio da política de fast track do ACNUR, devido a perseguições de gênero. ${ }^{4}$ Em suas entrevistas iniciais, ele fala, com uma voz fraca e titubeante, que, desde sua chegada, tem se sentido muito abalado, que não suporta mais morar no apartamento que lhe fora concedido pelo programa de reassentamento e, no entanto, tampouco se sente seguro para procurar um novo apartamento. Sente-se comprimido em sua nova morada, sob o preço de experimentar no corpo os efeitos de uma estranheza profunda. Durante a noite, tem pesadelos terríveis; as paredes da casa se despedaçam, e ele é expulso de seu interior em direção a lugares amorfos. Não é necessário dizer que, inicialmente, ele não relata a seu terapeuta os episódios que engendraram seu exílio, salvo o fato de que ele e seu namorado haviam sofrido muito devido à sua orientação de gênero.

No fim da segunda sessão, Vicente faz um comentário breve após um longo período de silêncio: "Preferia ter cicatrizes em meu corpo para poder saber falar sobre o que sinto". Ao ser perguntado por que pensou isso, ele responde que pensava que vir ao Brasil seria doloroso, mas pior do que a realidade do refúgio, era a irrealidade da dor: "Eu gostaria apenas de saber onde está minha dor."

$\mathrm{Na}$ sessão seguinte, ele conta ter visto na televisão uma reportagem sobre migrantes no Brasil: "Eu aprendi a palavra em português para o que eu lhe dizia na semana passada: é a solidão", diz ele, buscando no rosto do analista uma expressão de compreensão. Encorajado a falar mais sobre essa palavra estrangeira, ele acrescenta que "todos os migrantes experimentam a mesma solidão". No entanto há várias formas de sofrer, sugere o analista. Vicente refere-se então a uma cena do programa, na qual um jovem dizia ter sofrido a pior das violências, segundo Vicente, o estupro; ele silencia por um momento e pergunta: "A gente diz estuprado, né??”. Ao buscar a palavra no dicionário, ele a traduz a seu analista para lhe apresentar seu sofrimento. Efetivamente, como iria saber adiante, à

\footnotetext{
${ }^{3} \mathrm{O}$ caso a ser apresentado a seguir é fruto de um projeto de acompanhamento psicológico, realizado através de uma parceria entre a Associação Padre Antônio Vieira (ASAV), responsável, no Rio Grande do Sul, pelo reassentamento de refugiados vindos através do Alto Comissariado das Nações Unidas (ACNUR), e a Sigmund Freud Associação Psicanalítica (Sig). Ao fim dos atendimentos, todos os sujeitos foram consultados se estavam de acordo em ter fragmentos de seus atendimentos utilizados para pesquisa, sendo que somente seriam publicados os fragmentos clínicos de pacientes que não se encontrassem mais no Brasil, a fim de se preservar sua proteção como refugiados. Todos os nomes, localizaçôes e expressôes utilizados aqui foram modificados para preservar a identidade do atendido.

${ }^{4}$ A política de fast track encontra-se dentro das soluçôes duráveis de reassentamento propostas pelo ACNUR para a América Latina. Quando um refugiado, após se ter asilado em um segundo país, não encontra condiçôes de proteção para continuar neste, ele pode pedir refúgio num terceiro país.
} 
época de seu primeiro exílio, Vicente sofreu um episódio de perseguição, no qual milicianos haviam invadido sua casa e o molestado. Nessa época, seu pai já havia falecido, e ele decidia deixar sua mãe e a Colômbia para viver no Equador. Ainda que ele consiga narrar essa cena, Vicente não associa a dor vivenciada por ele à sua identificação com o jovem da televisão.

Ao longo de seu processo analítico, em numerosas ocasiões, Vicente emprega a língua portuguesa. Esse uso parece permitir-lhe defender-se do encontro com o traumático, inaugurando a arena da transferência, na qual a posição do analista passou gradualmente a atualizar a figura do namorado deixado no Equador. Este não teria podido vir junto ao Brasil, pois, segundo ele, eles não teriam podido provar junto ao ACNUR sua relação como casal. Na contratransferência, essa justificativa voltava ao analista como uma advertência de algo que Vicente não podia nem queria ver a respeito de seu relacionamento. Sua partida em fast track, tão abrupta, não lhe permitiu realizar nenhum ritual de adeus, salvo a promessa de que se reencontrariam no Brasil. Em sessão, Vicente fala do vazio deixado pelo companheiro, este último confundindo-se, a todo o momento, com a dor do refúgio. Nutria ele, assim, um laço com sua terra deixada a partir do voto de não acabar o relacionamento, investimento de objeto que lhe impedia de recomeçar sua vida no Brasil?

É sob esse fundo de ambivalência que, após longas "negociações" com seu analista, Vicente consegue ligar para seu namorado. Ao lhe falar no telefone, ele não o consegue escutar claramente, pois este não para de se deslocar pelas ruas. Essa chamada, investida longamente pela esperança de convencê-lo a se juntar a ele no Brasil, desfez-se ao termo de alguns minutos. Seu namorado parecia indiferente, como se Vicente nunca tivesse partido.

Em sessão, ele retoma a sensação física de estar enfrascado (expressão que ele traduz ao português, "comprimido"), visto que ele ouvia a voz lábil e oscilante de seu namorado. Convidado a falar sobre essa nova tradução que utiliza, Vicente a associa à posição passiva e ingênua que ele havia adotado no relacionamento. Essa constatação vira tema de muitas sessões, ao demarcar sua surpresa de não ter jamais pensado que isso dizia respeito não somente a sua relação atual, mas igualmente à sua sexualidade em geral. Há muito tempo ele se sente passivo em suas relações amorosas, mesmo que ele seja mais autônomo e responsável profissionalmente do que seus companheiros. Fato que desperta sua atenção sobre essa marca (invisível) que ele parece carregar consigo: espécie de assinatura "des-locando-se" junto com ele. Ante a emergência desse significante, o analista intervém, lembrando-o de seu desejo de possuir marcas sobre o corpo para melhor saber o que havia vivido. 
Após essa sessão, o processo analítico de Vicente começa de fato. Ele sai de seu apartamento, vai a festas, conhece pessoas, começa a trabalhar. Tudo aquilo que normalmente se atribui à integração social. Entretempo, seu namorado, Marco, pode finalmente ser nomeado na sessão. A possibilidade de que o relacionamento acabe o exaspera. Ele interprende um movimento para provar o contrário, mesmo se gradualmente ele se dê conta da impossibilidade da vinda de Marco ao Brasil. Com efeito, ele divide o namorado em "bom" e "mau" objeto. A partir das lembranças que retornam de sua relação, ele começa a fazer uma distinção entre dois tipos de homem: os negros/colombianos e os brancos/brasileiros. Entre a inscrição do objeto perdido e a eleição de novos, é na arena da transferência que essa tensão será atualizada.

\section{REFÚGIO NA LÍNGUA E SEUS DESTINOS TRANSFERENCIAIS}

No caso de Vicente, as traduções de significantes ao português sugerem que, ante o despertar de experiências arcaicas de rejeição e de desmembramento do corpo, o refúgio na língua de acolhimento lhe permite uma tomada de distância da língua na qual os episódios de violência foram vivenciados. Esse refúgio na língua permite-nos, portanto, deduzir três movimentos subjacentes ao envelopamento dos significantes pré-linguísticos pela língua de acolhimento.

1. O refúgio na língua de acolhimento permite uma espécie de extraterritorialidade do sujeito consigo mesmo. A tradução dos significantes "estuprado" e "comprimido" parece perfazer um mesmo circuito pulsional; oscilando entre o estrangeiro e o familiar, o ato de tradução permite ao sujeito criar uma zona de distanciamento e transitividade na qual seu sofrimento passa a ser estrangeiro a si mesmo. Ato que Altounian (2005) nomeia transnacionalização do trauma. Vicente fala do programa da tevê como se aquela cena não o implicasse, sendo o ato de tradução uma espécie de passarela interpsíquica entre ele e o analista.

2. O envelopamento dos significantes pré-linguísticos implica o acesso aos efeitos metafóricos e metonímicos da linguagem. Importante notar que, a partir da tradução do significante "comprimido", Vicente consegue associar as afecções de rejeição e despedaçamento que o assolavam desde sua chegada ao Brasil à sua posição ante seus relacionamentos. Essa construção em análise é condição de possibilidade para que um tratamento analítico seja possível para além da temporalidade congelada do exílio, visto que a asserção "preferia ter marcas no meu corpo para poder saber falar sobre o que sinto" dá lugar a um significante que lhe permite pensar em sua sexualidade e suas montagens de gozo. A figura do namorado, com todo o cortejo de angústias de separação que o engendra, 
deixa de ocupar o lugar de objeto insubstituível e passa a suscitar a angústia de castração diante da escolha do exílio.

3. O refúgio na língua como defesa contra a transferência. Não obstante, ao atualizar o fantasma de seu companheiro na figura do analista, ele coloca em ato aquilo que estava inibido durante toda sua estada no Brasil, a saber, suas eleiçôes de objeto atuais. Nesse momento, poder-se-ia intuir que ele perfaz sua integração social, mediante uma sintomatologia típica da frase dita depressiva, segundo Klein. No entanto, uma verdadeira luta contra a transferência se inaugura. Vicente passará algumas semanas a tentar provar que a relação com seu namorado não acabou: $\mathrm{o}$ analista branco/brasileiro alternando, assim, a posição de objeto bom/mau. Se aceitamos essa hipótese, seria interessante notarmos que o acesso a uma fase depressiva permite Vicente não cair em uma melancolização do exílio, uma vez que a cisão do objeto perdido o salva da atração mortífera com um vazio de figuralibilidade da terra de origem e seus objetos perdidos (Indursky, \& Oliveira 2016). É importante lembrar que, até aquele momento, Vicente não conseguia falar sobre os episódios que precipitam sua partida ao Brasil.

Não é de se surpreender que, para tanto, uma ação deva ter sido realizada a partir do psiquismo do analista, no qual o papel da transferência revela-se decisivo.

\section{FALSO POSITIVO: UM DESMENTIDO A SER TRADUZIDO IN ABSENTIA}

Passados alguns meses, o analista realiza um ato falho, esquecendo-se da sessão de Vicente. Devido a seus novos compromissos de trabalho, o analisando demanda mudar a data de seus encontros. Na semana seguinte, o analisando retorna, mas falando em português, em vez do habitual espanhol. Ante a questão se essa modificação teria uma relação com a ausência de seu analista, ele revela que inicialmente ele estava bravo, pensando inclusive que não deveria ter vindo ao Brasil. No entanto, passada a raiva inicial, ele começou a pensar em sua vida no Equador, mais especificamente nos dias que antecederam sua partida para o Brasil. As cenas de seu segundo exílio logo lhe invadem. Ele conta, então, que não foi exatamente uma perseguição de gênero que se passou; com efeito, alguns assaltantes haviam arrombado a casa (na qual moravam ele, seu companheiro e mais um amigo), roubando todos os seus bens e violando seu amigo. No entanto, e eis aqui a causa de seu constrangimento, Vicente não estava em casa no momento, chegando apenas um par de horas após o ocorrido. "Realmente, intervém o analista, esse fora outro desencontro que ele tivera. A diferença é que nesse foi você quem se 'atrasou'; no outro fui eu'. 
Vicente permanece alguns instantes incrédulo ante a possibilidade de que sua lembrança pudesse ser provocada pela associação livre evocada pela ausência do analista, mas, logo a seguir, ele verbaliza uma dúvida que lhe assombra durante muito tempo e que sempre o faz hesitar: talvez ele não seja de fato um verdadeiro refugiado. Perguntado por quê, ele diz que o primeiro exílio não tinha nada a ver com o segundo: o primeiro episódio continha perseguição de gênero, o segundo lhe parecia muito mais uma questão pontual de um bairro perigoso, no qual o motivo do assalto tocava a questão de grana e o acaso. Ou seja, revelava-se, assim, a dimensão da culpabilidade que assombra todo exilado e que, nesse caso, traduzia-se pela crença de ser um falso positivo, isto é, um caso de concessão de refúgio, mas cujos motivos não se enquadrariam nos requisitos elencados pelo ACNUR. Ele murmura que talvez tenha tomado uma decisão precipitada; uma forte angústia o toma ao lembrar-se da resposta, da pressa, da saída de casa com as roupas do corpo e uma mochila nas costas, a despedida atabalhoada, a sensação de que seu companheiro lhe evitava, a ligeira expectativa de que o exílio no Brasil possa ser sinônimo de um recomeço profissional.

Parêntese: no programa de soluções duráveis do ACNUR de reassentamento, não existe uma exigência de identidade entre a natureza da perseguição no primeiro e no segundo país. Basta que o segundo país não ofereça proteção ao refugiado para ele pedir novo reassentamento. Dito de outra forma, o medo de Vicente dizia menos da legitimidade jurídica de sua estada do que a dimensão de desautorização psíquica de seu próprio vivido.

Nesse sentido, o esquecimento do analista vem ao encontro desse episódio sem sujeito, despertando no analisando o sentimento transferencial de ser uma farsa, que ainda não pudesse ser verbalizado em análise. Esse encontro perdido com o real do trauma sugere uma espécie de desautorização da escolha do exílio de Vicente. Tudo se passa como se, desautorizado de ser sujeito de seus atos, ele não tivesse direito de sítio, visto que ele mesmo não estava presente no episódio que causava seu exílio. Ante a falta de tempo para planejar sua partida e realizar suas despedidas, o traço da desautorização do episódio parece acusar a ruptura traumática: "Não sou um verdadeiro refugiado, pois não sou eu o protagonista desta história". Não é senão no momento no qual a ausência do analista atualiza essa desautorização que o sujeito pode traduzi-la e que uma historicização de seu exílio pode tornar-se possível. Por sua associação-livre, Vicente pode finalmente testemunhar essa cena (à qual não comparecera) para ser sujeito de sua escolha; marco inaugural de seu desejo de estar no país e em análise.

Para tanto, uma operação realizou-se no seio do dispositivo analítico, sobre a qual nos parece interessante debruçar-se. 


\section{CONSIDERAÇÕES FINAIS}

"Enfim, lembremos que ninguém pode ser assassinado in absentia ou in effigie" (Sigmund Freud).

Essa expressão, ao menos curiosa, empregada por Freud (1912/1970) no fim de seu escrito sobre a dinâmica transferencial, remete-nos tanto ao nó de sua concepção sobre o luto quanto à sua generalização a todo trabalho psíquico ao longo de uma análise. Freud a utiliza quando fala da luta entre o analista e o analisando, ao afirmar que o primeiro leva a vitória contra a busca de satisfação pulsional deste. Essa busca seria realizada sob a forma alucinatória, projetando representações de objeto na figura do analista que deve, dessa feita, inevitavelmente sentir tais projeções, para atualizar a ausência do objeto. No entanto o emprego do termo assassinar parece abrir uma questão aqui. Alguns autores, como Fedida (2000), defendem a ideia que esse assassinato cumpre uma dupla função. Por um lado, ele realiza uma "desfascinação das imagens" pregnantes no psiquismo do analisando. Por outro, revelaria a tentação inconsciente do analista em ocupar o lugar do ideal de eu. Seria a partir desse assassinato que se abriria um lugar vazio, no centro da fala analítica, para o retorno de significantes da história do analisando. Sobre este último aspecto, o caso de Vicente nos sugere uma via importante de compreensão, visto que somente a ausência do analista - investido transferencialmente como ideal da comunidade de acolhimento (homem, branco, brasileiro) - permite-lhe revisitar o episódio recusado de seu exílio.

Em seu Seminário 6, Lacan (2016) afirma que a possibilidade de constituir o objeto no desejo passa pela perda do objeto; mais precisamente, pelo sacrifício de seu significante fálico. Se, em Freud (1912), é o assassinato da fonte de satisfação pulsional que instaura um lugar vazio no centro do dispositivo analítico, em Lacan (2016), esse assassinato é um sacrifício essencial; sacrifício do falo. Sacrifício que se dá em dois tempos. O primeiro decompõe o fantasma, o segundo o reinstaura. No caso Vicente, esse segundo tempo passa pela morte in absentia que se tornou possível pelo esquecimento da sessão por parte do analista. Visto que o ideal da comunidade pode cair, Vicente advém a reconstituir a cena de seu segundo encontro perdido do exílio.

A leitura lacaniana do luto, a partir de sua "re-inscrição" simbólica do objeto no desejo, permite-nos conceber que: "o que se passa nesse momento [segundo sacrifício], é a destruição ou perda do objeto que é reintegrado em seu quadro narcísico" (Lacan, 2016, p. 26). Se, num primeiro tempo, o exílio vem colocar o amigo de Vicente como o falo (único objeto com o qual pode contar), o segundo coloca-o no lugar fálico, ou seja, no lugar onde ele não é (mais), visto que o lugar aberto pela figura do analista (não sem relação à dimensão cultural) remete-o a 
sua posição diante de sua sexualidade. Se sua separação é seca, sem traços e rituais, é a morte do objeto, ao mesmo tempo persecutório e protetor, que o reinscreve na posição de sujeito, não sem o despertar de todo cortejo de angústias.

Nesse sentido, convém interrogar a temporalidade do exílio de Vicente. O tripé freudiano, inibição, sintoma e angústia, sugere um tempo lógico pertinente. Inicialmente, observa-se a inibição apresentada pelo signo da perda da capacidade de habitar sua nova morada. Vicente não apenas não consegue morar em lugar algum, mas o próprio ato de sair de casa para passear era vivido como uma expulsão ao vazio, no qual o borramento dos limites entre interior e exterior demonstravam que sua própria organização psíquica se encontrava em xeque. Com efeito, seus sonhos atualizam esse ato de expulsão que o exílio desenha. Num segundo tempo, quando ele advém pelo envelopamento desses elementos pré-linguísticos, a revisitar os episódios que o apresentam à sua posição ante seu companheiro e sua sexualidade, ele conhece a fase sintomática, a qual é marcada por um acesso depressivo.

Ao dividir seu companheiro em bom e mau objeto, Vicente coloca no seio de seu sofrimento a decisão entre sua nova e antiga realidade. Mesmo que ele apresente dificuldades para tematizá-la, seu sofrimento passa a ser "enredeado" pela transferência, o que lhe permitirá produzir um sintoma protetor. Finalmente, a partir da ausência do analista que lhe reenvia ao encontro perdido de seu segundo exílio, Vicente consegue ligar, em análise, esse episódio sem sujeito à angústia experimentada quando de sua segunda partida, provocando seus primeiros sonhos de expulsão e despedaçamento de seu corpo. Doravante, é em português que ele se dirigirá ao analista; refúgio na língua que o permite colocarse na cena de seu exílio, responsabilizando-o por sua escolha e engendrando um começo de historicização de seu percurso. 


\section{REFERÊNCIAS}

Altounian, J. (2005). L’intraduisible, Deuil, Mémoire, transmission. Paris: Dunod.

Altounian, J. (2007). Les héritiers et les traducteurs. Libres Cahiers pour la Psychanalyse, 16, 169-180.

Anzieu, D. (1996). Le Moi-Peau. Paris: Dunod.

Arendt, H. (2021). Hannah Arendt «Zur Person» Full Interview (with English subtitles). [YouTube]. Recuperado a partir de https://www.youtube.com/ watch?v=dsoImQfVsO4

Derrida, J. (2001). O monolinguismo do outro ou a prótese de origem. Braga: Campo das Letras.

Fedida, P. (2000). Le rêve architecte d'un lieu. L'inactuel, 5(3), 35-49.

Freud, S. (1895/1990). Projeto para uma psicologia científica. In J. Salomão (Trad.), Obras psicológicas completas de Sigmund Freud. (Vol. 1, pp. 387-466). Rio de Janeiro: Imago, 1990. (Publicado originalmente em 1895).

Freud, S. (1912/1970). La dynamique du transfert. In La technique psychanalytique. Paris: PUF, 1970. (Publicado originalmente em 1912).

Freud, S. (1914/2010). Recordar, repetir e elaborar. In P. C. de Souza (Trad.), Obras completas. (Vol. 10, pp. 193-209). São Paulo: Companhia das Letras, 2010. (Publicado originalmente em 1914).

Indursky, A., \& Conte, B. (2015, julho-dezembro). Trabalho psíquico do exílio: o corpo à prova de transição. Ágora, 18(2), 273-288.

Indursky, A. C., \& Oliveira, L. E. P. (2016). Sobre a melancolização do exílio. Revista Latinoamericana de Psicopatologia Fundamental, 19(2), 242-258.

Lacan, J. (1992). Le séminaire 17: l'envers de la psychanalyse. Paris: Seuil.

Lacan, J. (2016). O seminário: livro 6: desejo e sua interpretação. São Paulo: Jorge Zahar.

Laplanche, J. (1992). Le primat de l'autre en psychanalyse. Paris: Flammarion.

Moro, M-R., \& Lachal, C. (2012). Manuel des psychotraumatismes: cliniques et recherches contemporaines. Paris: La Pensée Sauvage. 
Nassikas, K. (2011). Exil de langues. Paris: PUF.

Nathan, T. (1984). Le corps pris: un élément dans l'etiologie de la vocation médicale. Perspectives Psychiatriques, 75, 17-20.

Pestre, E. (2010). La vie psychique des réfugiés. Paris: Payot.

Tourn, L. (2003). Les chémins de l'exil: vers une identité ouverte. Paris: Campagne Première. 